\title{
Diagnostic Usefulness of Nasal Biopsy in Wegener's Granulomatosis
}

\author{
ELIZABETH A. DEL BUONO, MD, AND ANDREW FLINT, MD
}

\begin{abstract}
Wegener's granulomatosis (WG) frequently involves the upper respiratory tract, and nasal mucosal biopsy is often initially used to establish the diagnosis. To evaluate the diagnostic efficacy of nasal biopsy in WG, we reviewed the pathologic features of 30 such biopsy specimens from 17 patients with well-documented WG. Active vasculitis (granulomatous or nongranulomatous) was identified in seven of the patients $(41 \%)$. The presence of extravascular foci of necrosis in lung biopsy samples has recently received attention as a characteristic feature of WG. Similar foci were found in the nasal samples from six of our patients, although vasculitis was absent in the samples from two of them. If extravascular foci of necrosis are regarded as characteristic or even diagnostic of WG, two additional patients in our series could be regarded as having had diagnostic nasal biopsies (nine of 17 patients). Nasal biopsy could thus be considered as diagnostic in $53 \%$ of the patients. Samples larger than $5 \mathrm{~mm}$ in greatest dimension were more likely to contain diagnostic features than were smaller samples $(P=0.002)$. HUM PATHOL 22:107110. Copyright 1991 by W.B. Saunders Company
\end{abstract}

Wegener's granulomatosis (WC) is a systemic disease which is frequenty lethal if untreated. While prompt treatment with immunosuppressive and cytotoxic agents can significantly alter the aggressive course of the disease, potentially severe side effects may result from therapy. In this light, histologic confirmation is usually sought to support the clinical diagnosis of W( before therapy is instituted. The nasal mucosa is ofien involved in WC; and is an easily accessible biopsy site." In this report we describe the pathologic manifestations of nasal mucosal involvement by WG and evaluate the diagnostic value of the nasal biopsi.

\section{MATERIALS AND METHODS}

Demographic data, clinical findings, treatment, and outcome were determined from the clinical records of 17 patients treated for WG at the University of Michigan Medical Center. Ann Arbor, MI. Each patient manifested signs and symptoms suggestive of WG and underwent nasal biopsy. Three patients were regarded as having had diagnostic specimens. Either a noninfectious granulomatous vasculitis of the lung (seven patients) or a necrotizing glomeru-

From the Department of Pathology, The Lniversity of Michigan, Ann Arlor, MI. Accepted for publication August $1,1990$.

Key u'ords: Wegener's granulomatosis, nasal biopsy.

Address correspondence and reprint requests to Elizabeth $A$. Del Buomo, MD, Department of Pathology, Box 0054, 1500 F Medical Center Dr. Ann Arbor, MI 48109-0054.

Copyright $\mathbb{C}: 1991$ by W.B. Saunders Compans

$0046-8177 / 91 / 2209-0003 \$ 5.00 \%$
Ionephritis (seven patients) was subsequently histologically documented in the remaining 14 patients whose nasal samples were regarded as nondiagnostic. The pathologic findings of the 30 nasal and paranasal sinuss biopsy samples obtained from these patients formed the basis of this study.

From two to four routinely stained histologic sections were reviewed lor each sample. Silver methenamine and Ziehl Neelsen-stained sections were examined for each case; fungal organisms and acid-fast bacilli were not identilied. The elastica of blood ressels was examined with the Moval pentachrome stain. The presence or absence of mucosal ulcers wats noted, as were the rvpes of inflammatory cells present in the submucosal stromal. The size of the biopsy sample was recorded and correlated with the presence of vasculitis (granulomatous of nongranulomatous) and with foci of extravascular necrosis (Fisher exact test).

Nongranulomatous vasculitis was defined as the presence of fibrinoid necosis and ramsmumal inflammators cells within the walls of blood vessels, primarily venules and anterioles, not located in or adjacent to an uker (Fig l). Enlarged, plump endorhelial cells, fibrin thrombi, and exmavasted red blood cells were other often-observed feafures. When associated with a histiocrtic infiltrate or multinurleated giant cells, the finding, were considered indicative of granulomatous vasculitis". (Fig 2). Rarely, palisades of histiocytes were arranged anomil these foci. Intimal fibrosis was considered to be evidence of prior vascular injury. Clamped or "granular" collagen comprised microscopic foci of extravascular necrosis (Fig 3). The altered collagen was often more eosinophilic than the adjacent uninvolved collagen. Cilusters of neutrophils were often present all these fori (Fig 4 ).

\section{OBSERVATIONS}

Clinical

The ages of the 17 patients ranged from 17 10 77 years (mean, 46 years); 10 of the patients were male. Sixteen patients presented with upper respiratory tract disorder signs or symptoms. None of the patients had a history of asthma or had asthmatic symptoms. The remaining patient initially sought medical attention because of dyspnea and increased sputum production; subsequent occurrence of upper respiratory tract disorder symptoms occasioned biopsy of the nasal mucosa.

Sixteen of the patients were treated with steroids and cytotoxic agents, and one of the patients also received radiation therapy to the nasal lesion. Clinical follow-up intervals ranged from 1 month to 24 years. A single patient was losi lo follow-up prior io the 


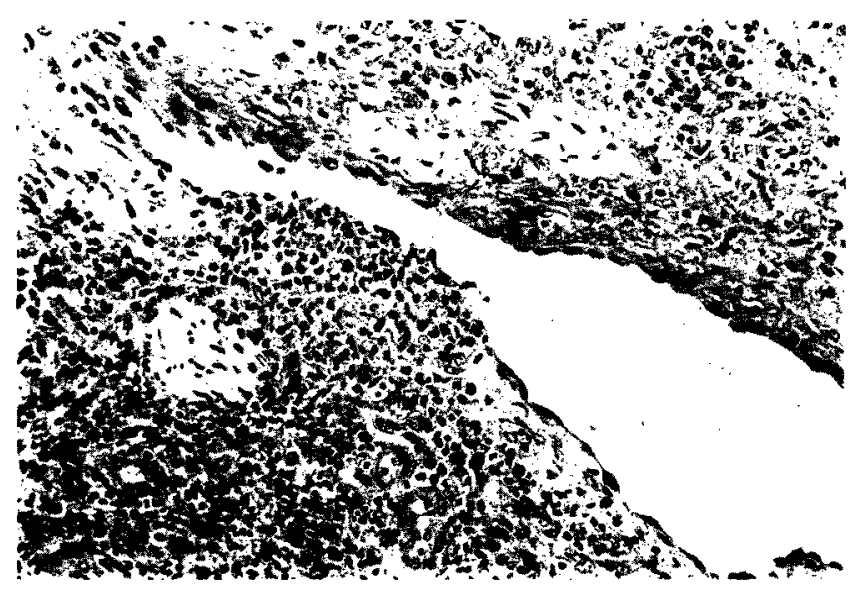

FIGURE 1. Nasal septum. Inflammatory cells involve a portion of a venule lined by endothelial cells. Inflammatory cells are scattered about the vessel as well. (Hematoxylin-eosin stain; magnification $x$ 250.)

initiation of therapy. A favorable response or complete remission was noted in 15 patients: one patient died from sepsis during the first month of therapy. The clinical findings are summarized in Table 1.

\section{Pathologic}

Biopsy samples obtained from four patients manifested granulomatous vasculitis (five of 30 samples). An additional three patients had evidence of nongranulomatous vasculitis (eight of 30 samples). Vasculitis was absent in the specimens obtained from the remaining 10 patients, although specimens from two of these patients demonstrated foci of extravascular fibrinoid necrosis. Nine biopsy samples obtained from four patients had both foci of extravascular necrosis and either granulomatous (one patient) or nongranulomatous vasculitis (three patients). Four biopsy samples from three other patients manifested granulomatous vasculitis although extravascular foci of Gibrinoid necrosis were absent. Intimal fibrosis or fibrous obliteration of blood vessel lumens was noted in nine samples obtained from seven patients.

Variable numbers of plasma cells, lymphocytes,

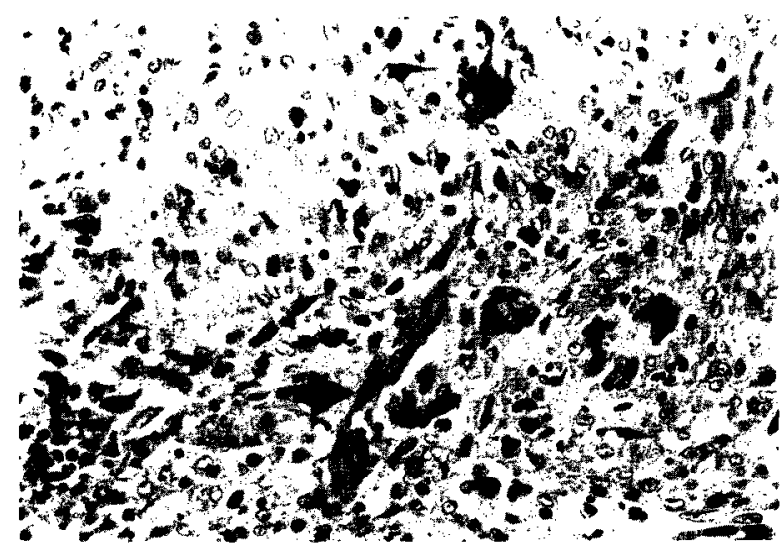

FIGURE 2. Multinucleated giant cells and other inflammatory cells partially destroy this blood vessel which is lined by swollen endothelial cells (arrow). (Hematoxylin-eosin stain; magnification $\times 250$.)

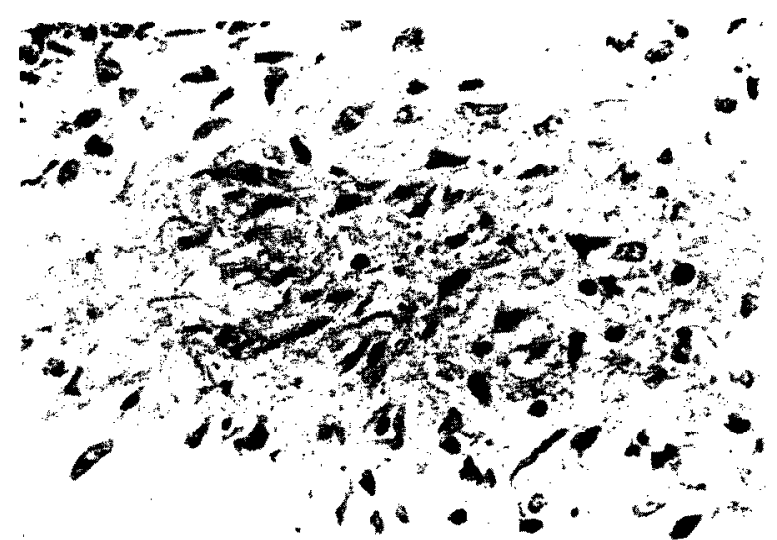

FIGURE 3. Extravascular necrotic focus. Note the granular appearance of the collagen. Most of the nuclei are intact. (Hematoxylin-eosin stain: magnification $\times 250$.)

and neutrophils were present in 27 of the samples, while scattered multinucleated giant cells and small numbers of eosinophils were present in 16 and 19 biopsy specimens, respectively. Ulceration of the mucosal surface was noted in 21 specimens. 'The pathologic features and their incidence are summarized in Table 2.

A sample size larger than $5 \mathrm{~mm}$ in at least one dimension was significantly correlated with the presence of an active vasculitis and foci of fibrinoid necrosis $(P=0.002)$. The presence or absence of granulomatous vasculitis did not correlate with sample size; this lack of correlation may have been due to the paucity of samples which manifested this finding (five of 30 specimens).

\section{DISCUSSION}

Wegener's granulomatosis was first described by Klinger and subsequently reported in greater detail by Wegener." The marked nasal ulceration and necrosis led Wegener to conclude that the nose was the primary site of the disease which subsequently produced inflammation and necrosis of the lungs and kidneys. ${ }^{\top}$ Over the ensuing years, however, diagnostic criteria primarily emphasized the necrotizing granulomatous lesions of the lower respiratory tract,

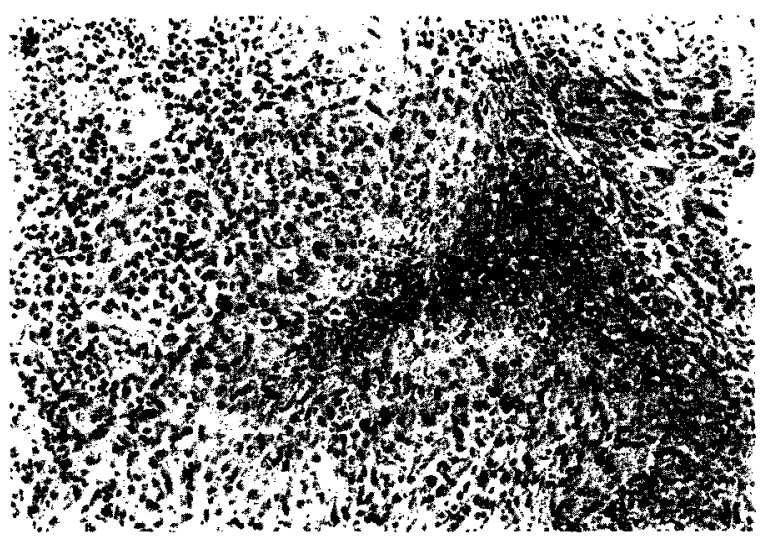

FICURE 4. Microabscess. Histiocytes surround the main cluster of neutrophils. (Hematoxylin-eosin stain; magnification $\times 125$.) 
TABLE 1. Clinical Findings

\begin{tabular}{|c|c|c|c|}
\hline $\begin{array}{l}\text { Patient } \\
\text { Xis. }\end{array}$ & $\operatorname{lgc} / 4 e^{2} x$ & $\begin{array}{l}\text { Presenting } \\
\text { Signs/Simptoms }\end{array}$ & I'herap! \\
\hline l & $3 y$ & $\begin{array}{l}\text { Hemoprysis, simusitis. } \\
\text { shaking chills. } \\
\text { diaphoresis }\end{array}$ & orlephes/pred \\
\hline 2 & HWM & $\begin{array}{l}\text { Sinusitis, chest pain. acral } \\
\text { chancesis }\end{array}$ & wliphos/pred \\
\hline 3 & bitit & 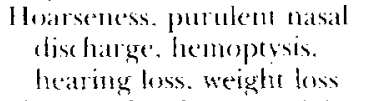 & whophosipred \\
\hline 1 & inis & $\begin{array}{l}\text { Simusitis, headache otalyial. } \\
\text { fever. chills, weakness. } \\
\text { weight loss }\end{array}$ & orlephos/pred \\
\hline 5 & $77 \cdot 1$ & $\begin{array}{l}\text { Simusitis, thinorrleat. } \\
\text { cough. hemoptysis }\end{array}$ & roluphos/pred \\
\hline ii & 29,31 & $\begin{array}{l}\text { Simusitis. muliple upper } \\
\text { respiratomy infections, } \\
\text { bloced nasal discharge } \\
\text { oralgia, ophthalgia. } \\
\text { hematumia }\end{array}$ & orlophos/pred \\
\hline T & $301 \mathrm{~F}$ & $\begin{array}{l}\text { Recurtenl epistaxis. } \\
\text { sinusitis, proptosis }\end{array}$ & rriophos/preal \\
\hline s & $4 \therefore M$ & 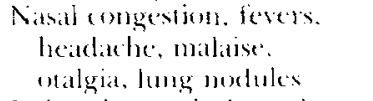 & crophos/pred \\
\hline ! & 17.11 & $\begin{array}{l}\text { Fpistaxis, nasal ulcers. hung } \\
\text { infill rates }\end{array}$ & \\
\hline 111 & 30111 & $\begin{array}{l}\text { Natsal congestion and } \\
\text { bloody discharge, otalgial. } \\
\text { perforated tympanic } \\
\text { membrane, weight loss }\end{array}$ & whophospred \\
\hline 11 & 291 & Saddle nose & aclophos/pred \\
\hline 11 & $53: 11$ & $\begin{array}{l}\text { Simusitis. pertorated natsal } \\
\text { septum. epistaxis }\end{array}$ & crlophos/pred \\
\hline 13 & 5.1 & $\begin{array}{l}\text { Epistials, hemoptesis, } \\
\text { cough, malaise: } \\
\text { pulmentats intilnates }\end{array}$ & crlophes/pred \\
\hline 1.1 & $311: \mathrm{F}$ & $\begin{array}{l}\text { Sinusitis, hemoptusis. } \\
\text { arthralgia }\end{array}$ & artephos/pred \\
\hline 15 & $51: 11$ & $\begin{array}{l}\text { Epistaxis, retorombital } \\
\text { pain. weakness }\end{array}$ & $\begin{array}{l}\text { oclophosipred. } \\
\text { radiation } \\
\text { therapy }\end{array}$ \\
\hline 16 & $56 \mathrm{~F}$ & $\begin{array}{l}\text { Maxillan simus pain. left } \\
\text { smus congestion }\end{array}$ & arlophosipred \\
\hline 17 & 67.11 & $\begin{array}{l}\text { spunm prochuctions } \\
\text { shortmess of breath }\end{array}$ & arcephos/pred \\
\hline
\end{tabular}

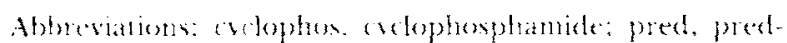
Hisolite.

and the presence of a generalized necrotizing vasculitis and glomerulonephritis. Carrington and Liebow later drew attention to a subset of patients in whom WG did not appear to involve the kidneys. "." Currently, it is generally accepted that the diagnosis of WC recpuires the presence of granulomatous inflammation, focal necrosis, fibrinoid degeneration. and multinucleate giant cells occurring in a patient with the appropriate signs and symptoms."
McDonald and his colleagues noted necrotizing epithelioid granulomas and vasculitis involving small arteries and veins in nasal samples obtained from 31 patients with W(;.- Some of the granulomas had zones of fibrinoid necrosis while others contained microabscesses. The investigators did not. however, report how many of the samples manifested these feattures. Fatuci and Wolff observed simnilar histologic findings in nasopharyngeal samples obtained from 10 patients with W(:." These workers described necrotiring grantomas with or withoul sasculitis in samples from six of the patients. Biopsy samples from the other four patients lacked specific inflammatory changes. Although Fauci and Wolff noted that nasopharyngeal symptoms predominated in virtually all of their patients, the diagnostic usefulness of the nasal biopser was not evaluated.

( )ur study demonstrates that, as rigidly defined above, granulomatous vasculitis is not often observed in nasal mucosal samples obtained from patients with W(; fou of 17 patients). To the extent that gramulomatous vasculitis is an essential feature, nasal mucosat biopsy does not appear to be frequently diagnostic. In this regard, our experience is similar to that ol Devanev and his coworkers. In a series of patients with WC, granulomatous vasculitis was observed by these investigators in just $7 \%$ of nasal specimens. ${ }^{12}$ If the presence of nongranulomatous vasculitis is also considered indicative of $W(B$, an additional three patients in our series maly be regarded as having had diagnostic biopsies. Thus, seven of 17 patients with W' had diagnostic nasal or paranasal samples.

Fienberg 13.1-t noted that extravascular necrosis or fibrinoid degeneration was usually present in W(; and often accounted for much of the tissue destruction. His observation has recently received renewed emphasis. ${ }^{1516}$ Addlitionally, Mark. et al ${ }^{16}$ have concluded from a study of 35 open lung biopsy samples that the earliest histologically visible lesion of WC is a small, usually extravascular, focus of collagen necrosis or fibrinoid degeneration.

Extravascular necrosis was observed in the present study almost as frequently ats was rasculitis (six and seven patients, respectively). While peripheral palisades of histiocrtes were nor found about these extravascular foci, multimucleated giant cells were frequently present in adjacent areas. Although not specific, the presence of scattered multinucleated giant cells in 16 of the samples may serve as a helpful diagnostic clue in the absence of a vasculitis or clearcut granulomatous inflammation.

Three patients had biopsy samples in which rasculitis was present in the absence of extravasculat ne-

TABLE 2. Pathologic Findings

\begin{tabular}{|c|c|c|c|c|c|c|c|c|}
\hline & $C \cdot-V$ & 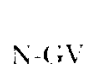 & $\mathrm{ENF}$ & $\begin{array}{l}\text { Vasculitis } \\
\text { and ENF }\end{array}$ & $\begin{array}{l}\text { Intimal } \\
\text { librosis }\end{array}$ & $\begin{array}{l}\text { (iiant } \\
\text { Ciells }\end{array}$ & $\begin{array}{c}\text { Stromal } \\
\text { Intlammation }\end{array}$ & C'kers \\
\hline Vo of patients & $4 / 17$ & $3 / 17$ & $6 / 17$ & +117 & $7 / 17$ & $101 / 1 \bar{i}$ & 117.17 & $1: 317$ \\
\hline No. of almples/hiopsies & $5 / 30$ & $8 / 311$ & $12 / 30$ & $4 / 30$ & $9 / 30$ & $16 / 30$ & 27311 & 21311 \\
\hline
\end{tabular}

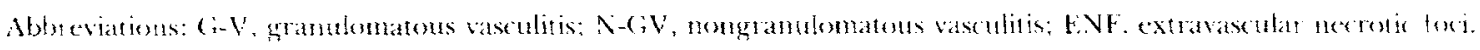


crosis. This observation differs from that of Fienberg who did not observe vasculitis in the absence of these extravascular foci. ${ }^{1 \cdot 4}$ Fienberg and McCluskey have stated that the diagnosis of WG can be established in many cases on the basis of biopsy specimens that do not demonstrate a vasculitis, but in which extravascular granulomas are present. ${ }^{15}$ Samples from two of our patients contained micronecrotic foci in the absence of an active vasculitis. In light of the views of Fienberg and McCluskey, these samples could be considered as diagnostic of $W(r$, thus raising to nine the number of patients in our study who had diagnostic nasal biopsy samples. 'To the extent that WG' is not a primary vasculitis, we agree with this view. The specificity of these findings has not been thoroughly evaluated, however, and infectious agents should always be excluded by careful examination.

Current therapy has markedly improved the prognosis of $W G$, although severe side effects may on occasion complicate the clinical course. ${ }^{1}$ While the diagnosis of WG rests upon characteristic clinical features, histologic confirmation is required to rule out other disorders which may closely mimic the signs and symptoms of $W G$, including infections, connective tissue disorders, Coodpasture's syndrome, and hypersensitivity vasculitis. ${ }^{1,17}$ When compared with lung and renal biopsy. nasal mucosal biopsy is an innocuous method for obtaining tissue for histologic confirmation. Nevertheless, based upon our experience, nasal biopsy is of somewhat limited usefulness when only traditional histologic criteria are used to interpret them (41\% of patients). In a clinical study of 77 patients with WG, Cordier et al ${ }^{18}$ showed that pattients died from WG primarily as a result of delays in diagnosis. The diagnostic efficacy of nasal biopsy is enhanced when extravascular foci of necrosis are regarded as diagnostic (52\% of patients). This enhancement will help support this procedure as the initial diagnostic procedure of choice. In order to further maximize the usefulness of these biopsies, we recommend obtaining samples larger than $5 \mathrm{~mm}$ in diame ter from areas away from ulcerated sites.

\section{REFERENCES}

1. Fatuci AS, Intyes BF, Katz. P. et al: Wegener's granulomacosis. Prospective clinical and therapeutic experience with 85 pat inonts for 21 wars. Ann Intern Med $98: 76-k 5,1983$

2. MeDonated TJ, DeRemé2 RA, Kern FB, et al: Nasal uanifestations of Wegentel's granulomatosis. Lanvengosepe 84:31012112,1974

3. Katrenstein ALA. Askin FB: Surgical Patholong of Nonneoplast ic Lung Disease. Philadelphia, PA Saunders, I990, pp 2592655

4. Iyatms V: Patholegy of the Nose and Palanasal Sinuses, in English (iN (ed): Otolaryingology. Philadelphia. PA, Lippincont, 1989, pp $4.3-45$

5. Klinger 11: Greneformen der Periarteriitis nodosa. Frankfurt $Z$ Pathol 42:455-480, 19:31

6. Wegener F: Itber generalisicrte. stptische Gefasserfrankungen. Itrh Itsch cies Pathol 29:202-210, 1936

7. Fienberg R: Vecrotizing granulomatosis and angiit is of the lungs. An J Clin Pathol 23:413-428. 1953

8. Dumeavage JA, Durkin (iE, L ehman RI I, et al: Dilemmas in the management of chronic natsal and sinus inflammatory diseases of unknown etiologr. Latrongoscope 95:1178-1183. 1985

4. Batsakis f(;. Luna MA: Midfarial necrorising lesioms. Semin Diage Pathol 4:601-116, 1987

10. Ciarington C.B, Licbow A: Limited lonms of angibis and

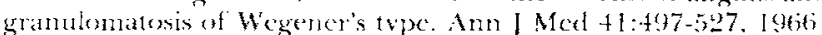

11. Fauci AS. Wolff SM: Wegener"s gramulomatosis: Studies in eightecon patients and a review of the literature. Medicine 52: $535-5000.1973$

12. Ievanter K. Travis W. Hoffman (i, ctal: Interpretation of head and neck biopsies in Wegener's granulomatosis. Iab Invest b():24 24,1989 (abstr)

13. Ficnberg R: Pathergic granulomatosis. An J Med 19:6og, 1955 (editrial)

14. Fienberg R: The protracted superticial phememenon in pathergic (Wegener's) granulomatosis. HoM Paterot, le:458-467. lost

15. Mcclusker R'I, Fienberg $\mathrm{R}$ : Vasculitis in primary vasculitides, granulomatoses, and connective tissute disedses. Hom

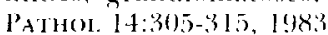

16. Mark Ej, Matsubata (o, Ian-Iiu NS, eal: The pulmonary biopst in the eatl clagnosis of Wegeners (pathergic) granulomatesis. Hon PATHol 19:1065-1071, 1988

17. Watters, LC: The gramulomatous vasculilides, in Kelley WN (ed): Iextbook of Internal Medicine. Philadelphia, PA. I.jppincet1. J489, p) 1914-1916

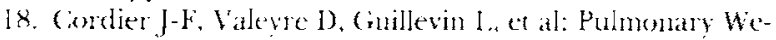
genters granulomatosis. A clinical and imaging study of 77 cascs. Cihest $(17: 906-912,1990$ 